\title{
DESAIN IKLAN LAYANAN MASYARAKAT PEMERINTAH
}

\author{
Agus Ganjar Runtiko \\ Fakultas Ilmu Sosial dan Ilmu Politik, Jurusan Ilmu Komunikasi \\ Universitas Jenderal Soedirman Banyumas, Jawa Tengah - 53122 \\ Telp/HP. (0281)635292 Ext. 214 / 085227788222 \\ email: ganjarruntiko@gmail.com \\ Naskah diterima tanggal 4 Mei 2013, disetujui pada tanggal 24 Juni 2013
}

\section{GOVERNMENT PUBLIC SERVICE ADVERTISING DESIGN}

\begin{abstract}
Public service advertising is one of the government strategies to promote the development program. At the national level, the government prefers television as a medium for advertising. As for the local level, the government usually tend to choose lower-cost ads. In Banyumas, many public service announcements using outdoor media such as billboards, banners, or posters. Characteristics of outdoor media that promotes design in attracting the attention of an audience became a challenge for designers. On the other hand, the messages also require the space in public service announcements. This study wants to know about how the execution of the design of outdoor advertising services in the community in efforts to combine the design with a message to be delivered. The study, sought to examine aspects of the design using the composition interpretation methods and verbal composition of outdoor advertising with discourse analysis methods. This research concludes that the government public service announcements desain still needs to be improved according to the rules of visual communication design.
\end{abstract}

Keywords: design, visual communication, public service advertising, government.

\begin{abstract}
Abstrak
Iklan layanan masyarakat merupakan salah satu strategi yang digunakan pemerintah untuk menyosialisasikan program pembangunan. Di tingkat nasional, pemerintah lebih memilih televisi sebagai media beriklan. Adapun di daerah, pemerintah biasanya cenderung memilih iklan yang berbiaya lebih murah. Di Banyumas, iklan layanan masyarakat banyak menggunakan media luar ruang seperti baliho, spanduk, ataupun poster. Kelebihan media luar ruang yang mengutamakan desain dalam menarik perhatian menjadi tantangan bagi pengiklan. Di sisi lain, pesan-pesan pembangunan juga membutuhkan ruang dalam iklan layanan masyarakat. Menarik untuk dikaji bagaimana eksekusi desain iklan luar ruang layanan masyarakat tersebut dalam usaha menggabungkan antara desain dengan pesan yang hendak disampaikan. Penelitian ini berusaha untuk mengkaji aspek desain dengan menggunakan metode interpretasi komposisi dan verbalisasi iklan luar ruang dengan metode analisis wacana. Hasil penelitian menyimpulkan bahwa desain iklan layanan masyarakat pemerintah masih perlu diperbaiki sesuai acuan dalam kaidah-kaidah desain komunikasi visual.
\end{abstract}

Kata kunci: desain, komunikasi visual, iklan layanan masyarakat, pemerintah. 


\section{PENDAHULUAN}

Pembangunan merupakan program yang terus berjalan, tidak akan ada habisnya, dan selalu ada sepanjang zaman. Ini sesuai dengan sifat manusia yang selalu berusaha memperbaiki diri. Hanya saja, pada setiap zaman manusia memiliki strategi tersendiri untuk membangun bangsanya.

Indonesia telah mengalami berbagai sistem pemerintahan. Semua sistem tersebut berujung pada gaya membangun pemerintah. Pada sistem pemerintahan otoriter, pembangunan relatif bersifat top-down, semua jenis komunikasi berasal dari pemerintah dan masyarakat grass root yang harus menyesuaikan diri. Sebaliknya, pada sistem pemerintahan yang demokratis, pemerintah berusaha menampung aspirasi dari masyarakat, sehingga gaya komunikasinya sering disebut sebagai bottom-up, di mana pemerintah yang kemudian menyesuaikan diri dengan apa yang menjadi aspirasi masyarakatnya.

Gaya komunikasi yang dibawa dalam setiap pemerintahan terekam dalam dokumendokumen, baik yang terbuka maupun tertutup (rahasia). Salah satu dokumen yang dapat merekam gaya komunikasi pemerintah adalah melalui pesan-pesan yang disampaikan di berbagai media. Pada masa pemerintahan otoriter, pesan yang disampaikan bisa jadi masuk ke dalam pemberitaan dengan gaya berita yang sudah dikendalikan sedemikian rupa sehingga membuat pencitraan pemerintah di masyarakat terkesan baik. Gaya komunikasi seperti ini dimungkinkan karena pemerintah memiliki wewenang yang luas dalam mengendalikan komunikasi. Hal tersebut tidak berlaku bagi pemerintahan demokratis. Pemerintahan yang demokratis mau tidak mau harus membuat pesan yang lebih elegan, dengan tidak mengeksploitasi ruang publik secara berlebihan.

Salah satu strategi pesan pemerintah untuk menarik perhatian masyarakat dengan menggunakan iklan. Iklan yang dikeluarkan pemerintah ini lebih dikenal dengan istilah iklan layanan masyarakat (public service advertising), karena sifat iklan yang tidak berusaha mengejar keuntungan material. Iklan layanan masyarakat cenderung mengajak masyarakat untuk berpartisipasi dalam program-program yang dicanangkan pemerintah. Hal ini sesuai dengan yang dikatakan Kasali (1995) tentang jenis iklan yang sengaja dibuat untuk menggerakkan solidaritas masyarakat terhadap permasalahan yang mereka hadapi, yakni kondisi yang mengancam keserasian dan kehidupan umum.

Sifat iklan, bagaimanapun, adalah mengajak atau mempersuasi. Harapan pemerintah, beriklan di media massa ataupun media nonmassa adalah memperoleh perhatian masyarakat. Di sisi lain, informasi yang berkembang di ruang publik masyarakat tidak semata-mata informasi monoton. Pesan yang dibuat harus bersaing dengan informasiinformasi lain yang tidak kalah menariknya. Sampai di titik ini, pesan yang dibuat harus mampu menarik perhatian masyarakat yang menjadi sasaran pesan tersebut.

Dinamika kehidupan telah mengantar manusia pada kemajuan zaman, dengan menyeret perubahan besar dalam setiap aspek kehidupan masyarakat. Arus perkembangan komunikasi dan informasi modern yang serba komputerisasi menjadi salah satu faktor pendorong terjadinya perubahan tersebut. Proses komunikasi semakin rumit, dengan tuntutan adanya penggunaan bahan-bahan visual (gambar, foto, film, transparansi, bagan, diagram, animasi) dalam sebuah pesan. Hal ini juga terkait dengan adanya perubahan dalam cara pandang masyarakat terhadap sebuah pesan. Pesan akan semakin mudah dipahami apabila terdapat bentuk visual di dalamnya.

Permasalahan yang akan dikaji dalam penelitian ini adalah bagaimana pesan-pesan pemerintah disampaikan dalam iklan layanan masyarakat, yang secara spesifik akan mengamati:

1. Jumlah/kuantitas iklan layanan masyarakat pemerintah dibanding iklan komersial;

2. Desain iklan layanan masyarakat pemerintah;

3. Tata bahasa verbal iklan layanan masyarakat pemerintah;

Dengan demikian, penelitian ini 
mempunyai beberapa tujuan yang hendak dicapai, antara lain:

1. Mengetahui jumlah iklan layanan masyarakat pemerintah yang terletak di jalan utama Banyumas;

2. Mengetahui dan menilai desain iklan layanan masyarakat pemerintah;

3. Mengetahui dan menilai tata bahasa verbal iklan layanan masyarakat pemerintah.

Adapun manfaat penelitian ini yakni:

1. Memberikan pengayaan teoretis terhadap kajian komunikasi visual maupun periklanan;

2. Mampu menjadi dasar-dasar penelitian selanjutnya mengenai dampak media, dan komunikasi pembangunan;

3. Dapat menjadi masukan bagi pemerintah dalam membuat iklan layanan masyarakat yang berbasis pada kaidah desain yang baik;

4. Masyarakat sebagai audiens iklan agar dapat memahami karakteristik pesan pemerintah melalui iklan.

\section{LANDASAN KONSEP}

Ditinjau dari perspektif komunikasi, iklan dianggap sebagai teknik penyampaian pesan yang efektif dalam penjualan produk. Oleh karenanya, dalam aktivitas perpindahan informasi tentang suatu produk yang diiklankan kepada khalayak tentunya harus mengandung daya tarik sehingga mampu menggugah perasaan khalayak. Hal tersebut berarti, melalui informasi yang diperoleh dari iklan, diharapkan masyarakat mempunyai rasa tertarik, membutuhkan, dan rasa ingin membeli barang atau jasa yang diiklankan, atau dapat disebutkan bahwa informasi tersebut kemudian menjadi seperangkat pengetahuan yang membimbing dan mengarahkan masyarakat pada keputusan untuk membeli (Sumartono, 2002).

Iklan merupakan media komunikasi persuasif yang dirancang sesuai dengan karakter media, segmen pasar, dan kebutuhan masyarakat untuk mendapat tanggapan positif mengonsumsi produk untuk membantu tercapainya tujuan pemrakarsa. Produsen sebagai pemrakarsa mewujudkan iklan untuk mengomunikasikan produknya merupakan salah satu bentuk strategi pemasaran.

Iklan merupakan bentuk penyampaian pesan yang menawarkan suatu produk yang ditujukan kepada masyarakat melalui suatu media yang memengaruhi masyarakat untuk membeli (Jefkins, 1997). Aspek behavioral sangat ditonjolkan dalam definisi yang dibangun oleh Jefkins, sehingga seolah-olah tugas iklan semata-mata adalah membuat orang lain bertindak sesuai dengan pesan yang diberikan oleh pengiklan. Definisi yang lebih holistis dapat dijumpai pada Wright dalam Liliweri (1992) yang mengatakan bahwa tujuan iklan adalah untuk memotivasi pembeli potensial dan mempromosikan suatu produk atau jasa untuk memengaruhi pendapat publik, memenangkan dukungan publik untuk berpikir atau bertindak sesuai dengan keinginan pemasang iklan. Sedangkan Dyer (1982) mendefinisikan periklanan secara lebih sederhana, yakni 'drawing attention to something', or notifying or informing somebody of something.

Para pengiklan pada dasarnya tidak menjual barang atau produknya melalui iklan, akan tetapi menjual impian dan harapan. Pengiklan cenderung menciptakan situasi "persuasi" terhadap diri sendiri, artinya bahwa orang tidak akan secara terus menerus dirayu untuk membeli, justru diberikan kesadaran mengenai adanya suatu kebutuhan, diberi informasi mengenai ketersediaan suatu produk dan pada akhirnya diberi kesempatan untuk memutuskan sendiri apakah akan membeli produk tersebut atau tidak.

Selain untuk kepentingan komersil, iklan juga ada yang mengedepankan kepentingan nonkomersil atau semikomersil. Ada jenis iklan yang dibuat untuk menggerakkan solidaritas masyarakat terhadap permasalahan yang mereka hadapi, yakni kondisi yang mengancam keserasian dan kehidupan umum (Kasali, 1995). Iklan yang dimaksud adalah iklan layanan masyarakat yang kegunaannya adalah memperbaiki masalah-masalah yang menyangkut perubahan nilai dan kebiasaan masyarakat. Iklan layanan masyarakat termasuk dalam iklan nonkomersial sehingga 
disebarluaskan melalui pembelian ruang dan waktu dan dilaksanakan secara nonprofit atau tidak mencari keuntungan (Susanto, 1989). Sedangkan Nuradi (1996) mendefinisikan iklan layanan masyarakat sebagai jenis periklanan yang dilakukan pemerintah, suatu organisasi komersial ataupun nonkomersial untuk mencapai tujuan sosial, terutama untuk meningkatkan kesejahteraan masyarakat.

iklan layanan masyarakat untuk mengomunikasikan kebijakan pemerintah dalam menghadapi permasalahan yang timbul di masyarakat. Iklan ini seringkali berisi ajakan dan seruan dari pemerintah agar masyarakat peduli pada permasalahan di sekitarnya, sehingga masyarakat memiliki kesadaran bersama untuk memperbaikinya. Iklan layanan masyarakat merangsang masyarakat menciptakan lingkungan sosial yang kondusif dan nyaman untuk kehidupan bersama. Selain untuk menanggapi permasalahan yang timbul di masyarakat, iklan layanan masyarakat biasanya juga digunakan untuk memperingati agenda tertentu seperti Hari Kartini, Hari Pendidikan Nasional, Hari Pahlawan, dan lain sebagainya.

Secara teori, iklan layanan masyarakat tidak berbiaya, namun seperti halnya iklan produk komersil lainnya, iklan layanan masyarakat juga muncul di beberapa media massa dan media nonmassa seperti radio, televisi, media cetak, serta papan reklame atau iklan luar ruang. Kemunculan iklan layanan masyarakat di media massa sangat tergantung pada kebijakan media massa dalam meluangkan sebagian ruang atau waktunya. Ada media massa yang mengenakan tarif, ada juga yang membebaskan tarif dengan konsekuensi iklan yang dipasang tersebut hanya mendapatkan ruang, atau waktu yang tidak marketable.

Di dalam sebuah iklan terdapat berbagai aspek yang berperan dalam menarik perhatian audiens. Salah satu yang memiliki peranan besar dalam iklan adalah desainnya, terutama iklan yang dapat diamati secara visual. Desain iklan ini kemudian dikaji dalam ilmu komunikasi salah satunya melalui kajian desain komunikasi visual. Desain komunikasi visual ini menempatkan seni sebagai keunikan sekaligus kekuatan khas yang dapat mendatangkan nilai-nilai pengalaman tersendiri bagi khalayak pengguna atau penikmatnya. Menurut Hadi (2007), desain komunikasi visual ini hadir di dalam satu paket layanan fungsional komunikasi yang berwujud produk ataupun jasa.

Terdapat tiga unsur pokok dalam frase desain komunikasi visual, yakni desain, komunikasi, dan visual. Istilah desain merupakan hasil serapan dari Bahasa Inggris, design yang berarti art of making such drawing, etc (Manser, 1995). Sedangkan komunikasi dimaknai sebagai penyampaian suatu pesan dalam bentuk tanda-tanda sebagai panduan pikiran dan perasaan berupa ide, gagasan yang dilakukan seseorang kepada orang lain, baik secara langsung (tatap muka) ataupun tidak langsung (melalui media) dengan tujuan mengubah sikap atau perilaku. Unsur terakhir, visual, diartikan dalam Kamus Besar Bahasa Indonesia sebagai dapat dilihat dengan indera penglihatan (mata) atau juga berdasarkan penglihatan. Sehingga, desain komunikasi visual dapat diartikan sebagai seni merancang penyampaian tanda-tanda yang mengandung pengertian tertentu oleh seseorang kepada orang lain melalui media kasatmata atau dapat dilihat.

Desain komunikasi visual adalah desain yang mempunyai peran mengomunikasikan pesan atau informasi kepada pembaca dengan berbagai kekuatan visual, seperti tipografi, ilustrasi, warna, garis, layout, dan sebagainya dengan bantuan teknologi (Supriyono, 2010). Desainer komunikasi visual berusaha untuk memengaruhi sekelompok pengamat. Mereka berusaha agar kebanyakan orang dalam target group (sasaran) tersebut memberikan respon positif kepada pesan visual. Oleh karena itu, desain komunikasi visual harus komunikatif, dapat dikenal, dibaca, dan dimengerti oleh target group tersebut.

Sebagai bahasa, desain komunikasi visual adalah ungkapan ide dan pesan dari perancang kepada khalayak yang dituju melalui simbol berujud gambar, warna, tulisan, dan lainnya. Desain komunikasi visual akan komunikatif apabila bahasa yang disampaikan itu dapat dimengerti oleh 
khalayak dan akan berkesan apabila dalam penyajiannya itu terdapat suatu kekhasan atau keunikan sehingga dapat tampil secara istimewa, mudah dibedakan dengan yang lain. Maka, dalam berkomunikasi, diperlukan sejumlah pengetahuan yang memadai seputar siapa khalayak yang dituju, dan bagaimana cara terbaik berkomunikasi dengan mereka. Semakin baik dan lengkap pemahaman terhadap hal-hal tersebut, maka akan semakin mudah untuk menciptakan bahasa yang komunikatif. Dalam perkembangannya selama beberapa abad, desain komunikasi visual mempunyai tiga fungsi dasar, yaitu sebagai sarana identifikasi, sebagai sarana informasi dan instruksi, dan yang terakhir sebagai sarana presentasi dan promosi (Cenadi, 1999).

Fungsi dasar yang utama dari desain komunikasi visual adalah sebagai sarana identifikasi. Identitas seseorang dapat mengatakan tentang siapa orang itu, atau dari mana asalnya. Demikian juga dengan suatu benda atau produk, jika mempunyai identitas akan dapat mencerminkan kualitas produk itu, dan mudah dikenali, baik oleh produsen maupun konsumennya. Orang akan lebih mudah membeli minyak goreng dengan menyebutkan merek $\mathrm{X}$ ukuran $\mathrm{Y}$ liter daripada hanya membeli minyak goreng saja, atau orang akan membeli minyak goreng merek X karena logonya yang berkesan bening, bersih, dan "sehat".

Fungsi kedua desain komunikasi visual adalah sebagai sarana informasi dan instruksi. Sebagai sarana informasi dan instruksi, desain komunikasi visual bertujuan menunjukkan hubungan antara suatu hal dengan hal yang lain dalam petunjuk, arah, posisi, dan skala, contohnya peta, diagram, simbol, dan penunjuk arah. Informasi akan berguna apabila dikomunikasikan kepada orang yang tepat, pada waktu dan tempat yang tepat, dalam bentuk yang dapat dimengerti, dan direpresentasikan secara logis dan konsisten. Simbol-simbol yang kita jumpai sehari-hari, seperti tanda dan rambu lalu lintas, simbolsimbol di tempat-tempat umum seperti telepon umum, toilet, restoran, dan lain-lain harus bersifat informatif dan komunikatif, dapat dibaca dan dimengerti oleh orang dari berbagai latar belakang dan kalangan.

Fungsi ketiga desain komunikasi visual adalah sebagai sarana presentasi dan promosi. Tujuan dari desain komunikasi visual sebagai sarana presentasi dan promosi adalah untuk menyampaikan pesan, mendapatkan perhatian (atensi) dari mata (secara visual) dan membuat pesan tersebut dapat diingat, contohnya poster. Penggunaan gambar dan kata-kata yang diperlukan sangat sedikit, mempunyai satu makna dan mengesankan. Umumnya, untuk mencapai tujuan ini, maka gambar dan kata-kata yang digunakan bersifat persuasif dan menarik, karena tujuan akhirnya adalah menjual suatu produk atau jasa sebagai suatu proses beriklan.

Demi menghasilkan desain iklan yang berkualitas, diperlukan pertimbangan yang cerdas dalam mengorganisasikan elemenelemen grafis (garis, warna, bentuk, tekstur, dan ruang) sesuai dengan prinsip-prinsip desain secara tepat dengan memperhatikan keterbatasan ruang dan bahan. Untuk itulah diperlukan kreativitas untuk menghasilkan desain yang kreatif. Salah satu prinsip yang dikenal luas adalah seperti yang dinyatakan oleh McElroy dalam Pujiriyanto (2005):

1. Keseimbangan, artinya halaman harus tampil seimbang dan harmonis;

2. Penekanan, memberikan pengertian bahwa tidak semua unsur grafis adalah sama pentingnya dan perhatian audiens harus berfokus pada satu titik;

3. Irama, artinya pola yang diciptakan dengan mengulangi dan membuat variasi dari unsur grafis yang ada dan menggunakan ruangan (unsur grafis) untuk memberikan kesan gerak (dinamis);

4. Kesatuan, mengandung pengertian semua bagian dan unsur grafis bersatu-padu dan serasi sehingga pembaca memahaminya sebagai suatu kesatuan. Desain yang efektif menerapkan prinsip variasi dalam kontinuitas;

Sebagai tambahan, menurut McElroy, ciri desain kreatif adalah dapat menarik perhatian; tulisan di dalamnya mudah dibaca dan dimengerti; informasi tulisannya dilengkapi dengan informasi visual sehingga dapat dipahami khalayak. Semua hal tersebut 
dapat mengangkat intisari tulisan dan menceritakan suasana setempat serta perasaan orang yang bersangkutan.

\section{METODE PENELITIAN}

Penelitian ini memfokuskan diri pada analisis iklan layanan masyarakat yang dibuat pemerintah di Banyumas. Lebih tepatnya adalah iklan layanan masyarakat yang berada di luar ruang (outdoor advertising). Setelah melalui observasi sementara, penelitian ini mengambil lokasi di Jalan Jenderal Soedirman Banyumas sebagai jalan yang dianggap menjadi representasi keadaan jalan di Banyumas.

Metode penelitian yang dipakai adalah metode analisis wacana. Secara spesifik, penulis mengutamakan pendekatan "interpretasi komposisi" (compositional interpretation) sebagaimana yang disarankan oleh Rose (2001) untuk menganalisis gambar. Rose mengatakan bahwa pendekatan ini menawarkan kosakata rinci untuk mengekspresikan penampilan gambar. Sebagai pelengkap, penulis juga menganalisis verbal pada teks yang dianggap perlu, di sini penulis menggunakan analisis wacana persuasi, yang menurut Fachrudin (1988) merupakan jenis wacana yang mengajak seseorang melakukan dan menerima sesuatu. Dalam hal ini, yang dikaji adalah satuansatuan lingual yang terdiri dari kalimat, klausa, frase, kata, atau morfem. Halliday dan Hasan (1992) menyebutkan bahwa wacana (teks) sebagai bahasa yang berfungsi, yakni bahasa yang sedang melaksanakan tugas tertentu dalam konteks tertentu yang berlainan dengan kata-kata atau kalimat lepas.

Penelitian ini berusaha mengumpulkan data melalui dokumentasi yang terdapat di masyarakat, misalnya saja informasi dalam karya tulis di buku, informasi yang ada di internet, maupun informasi yang ada di media massa. Selain itu, penulis juga melakukan observasi mengenai tata letak iklan luar ruang, pemilihan lokasi, serta ukurannya. Kesemuanya itu merupakan sebagian dari aspek-aspek yang hendaknya dipertimbangkan dalam desain.
Analisis data adalah proses mengorganisasikan dan mengurutkan data ke dalam pola, kategori, dan satuan uraian dasar sehingga dapat ditemukan tema dan dirumuskan hipotesis kerja seperti yang disarankan oleh data Patton dalam Moleong (2007). Penulis dalam penelitian ini menggunakan analisis data interaktif. Menurut Miles dan Huberman (1992), model analisis ini mengaitkan tiga komponen pokok analisis data yaitu: 1) Reduksi Data, yaitu proses seleksi pemusatan perhatian pada penyederhanaan, pengabstrakan, dan transformasi data 'kasar' yang muncul dari berbagai catatan tertulis di lapangan; 2) Penyajian Data, adalah kumpulan informasi yang tersusun dan memberi kemungkinan adanya penarikan kesimpulan dan pengambilan tindakan; 3) Penarikan simpulan, di mana dalam proses ini penulis mulai melakukan interpretasi, yaitu memberikan makna pada data atau informasi yang telah disaji. Proses analisis ini berjalan terus-menerus seperti sebuah siklus.

\section{HASIL PENELITIAN DAN PEMBAHASAN}

Banyumas merupakan bekas karesidenan serta salah satu kota "tua" di Indonesia. Andil Banyumas dalam perkembangan negeri ini cukup besar. Banyak tokoh penting Indonesia yang berasal dari Banyumas, pun demikian pula keputusankeputusan monumental pernah hadir di sini. Beberapa ratus tahun setelah kelahirannya, Banyumas kini telah menjadi salah satu tujuan investasi utama di Jawa Tengah bagian selatan. Dengan posisinya yang seolah "sendirian" berada di antara perbatasan Jawa Barat dan Jawa Tengah bagian selatan, menjadikan Banyumas bagaikan magnet bagi kedatangan para investor.

Gelombang investasi yang masuk ke sebuah wilayah sejatinya adalah usaha kesejahteraan bagi warganya. Kesejahteraan warga ini tidak akan dapat diraih tanpa peraturan perundangan yang tegas, mengikat, dan mempunyai kekuatan hukum yang kuat. Selain itu, seluruh stakeholders (pemangku 
kepentingan) harus memahami betul mengenai peraturan perundangan yang berlaku di wilayah setempat. Pemangku kepentingan diharapkan juga dapat memahami dan memanfaatkan fasilitasi dari pemerintah setempat secara optimal guna pengembangan investasi yang lebih tinggi lagi.

Salah satu upaya pemerintah setempat dalam menyosialisasikan peraturan perundangan yang berlaku, serta sosialisasi fasilitasi yang diberikan pemerintah dalam pengembangan kota adalah melalui iklan layanan masyarakat. Dari pengamatan penulis, iklan yang banyak digunakan oleh pemerintah daerah Banyumas adalah melalui iklan luar ruang, yang memang lebih ekonomis. Iklan jenis ini tersebar di berbagai tempat di sudut kota, dan tidak terpusat pada titik tertentu saja.

Penulis menentukan Jalan Jenderal Soedirman sebagai lokasi kajian karena berbagai pertimbangan. Pertama, Jalan
Jenderal Soedirman merupakan jalan terpanjang di Kota Purwokerto, ibukota Banyumas. Jalan ini membentang sepanjang 6 $\mathrm{km}$ dari bagian barat Purwokerto hingga ujung timur Kota Satria. Melintasi tiga kecamatan, dan beberapa kelurahan. Kedua, di deretan jalan ini banyak terdapat pertokoan yang menunjang kegiatan ekonomi masyarakat Banyumas, boleh dikatakan jalan ini merupakan urat nadi perekonomian di Banyumas. Ketiga, di sepanjang lajur jalan ini juga terdapat beberapa instansi pemerintah, seperti PLN, Kantor Bupati, Lembaga Pemasyarakatan, Badan Pertanahan Nasional, dan lain sebagainya, yang biasanya selalu menempatkan iklan layanan masyarakat di lokasinya berada. Peta jalan-jalan utama di Banyumas seperti terlihat pada gambar 1.

Tampak dari peta tersebut, bahwa Jalan Jenderal Soedirman benar-benar berada di tengah kota. Posisinya yang strategis memungkinkan iklan luar ruang memperoleh porsi perhatian yang lebih dari masyarakat.

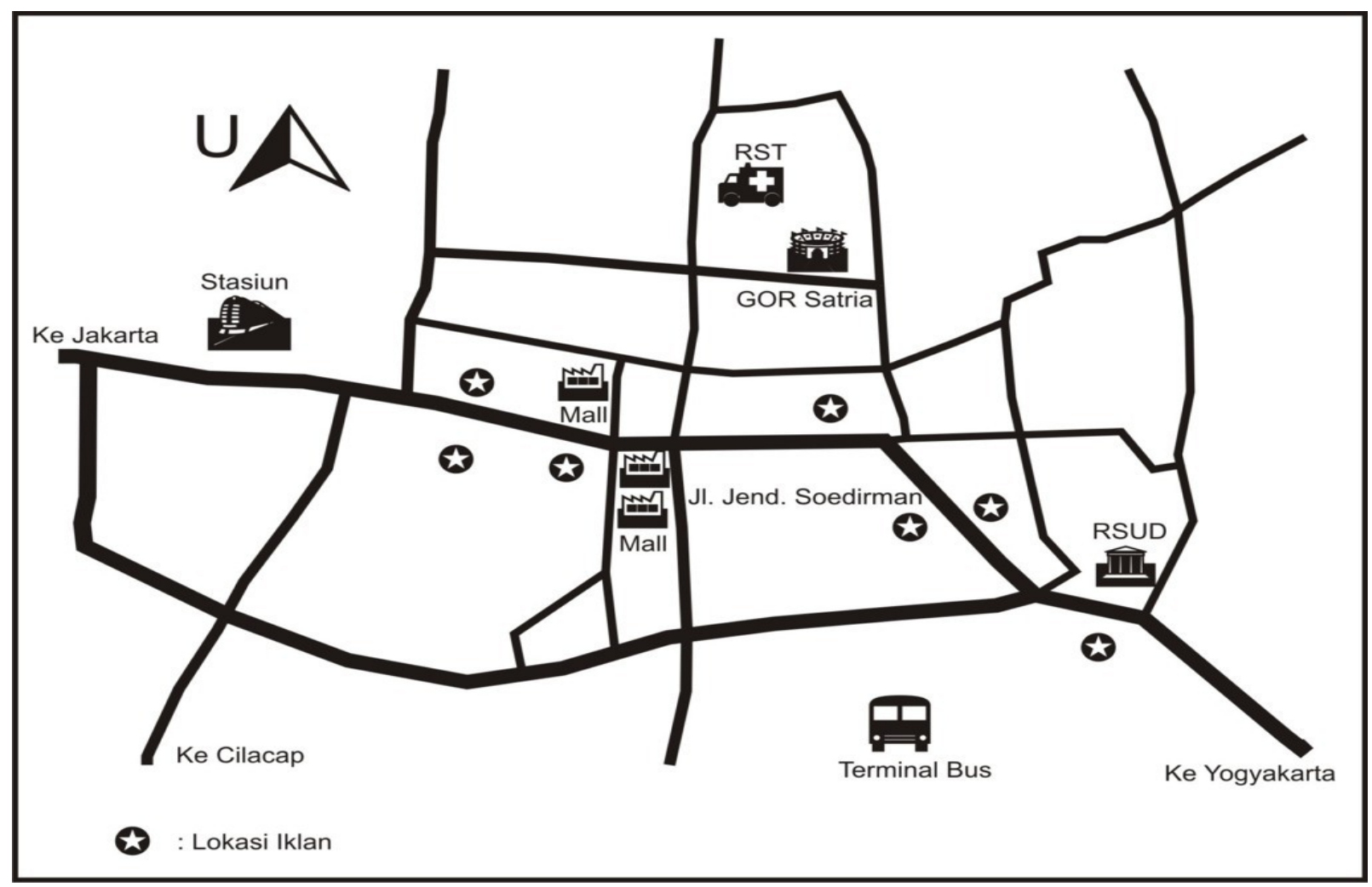

Gambar 1

Peta Jalan Utama di Banyumas 


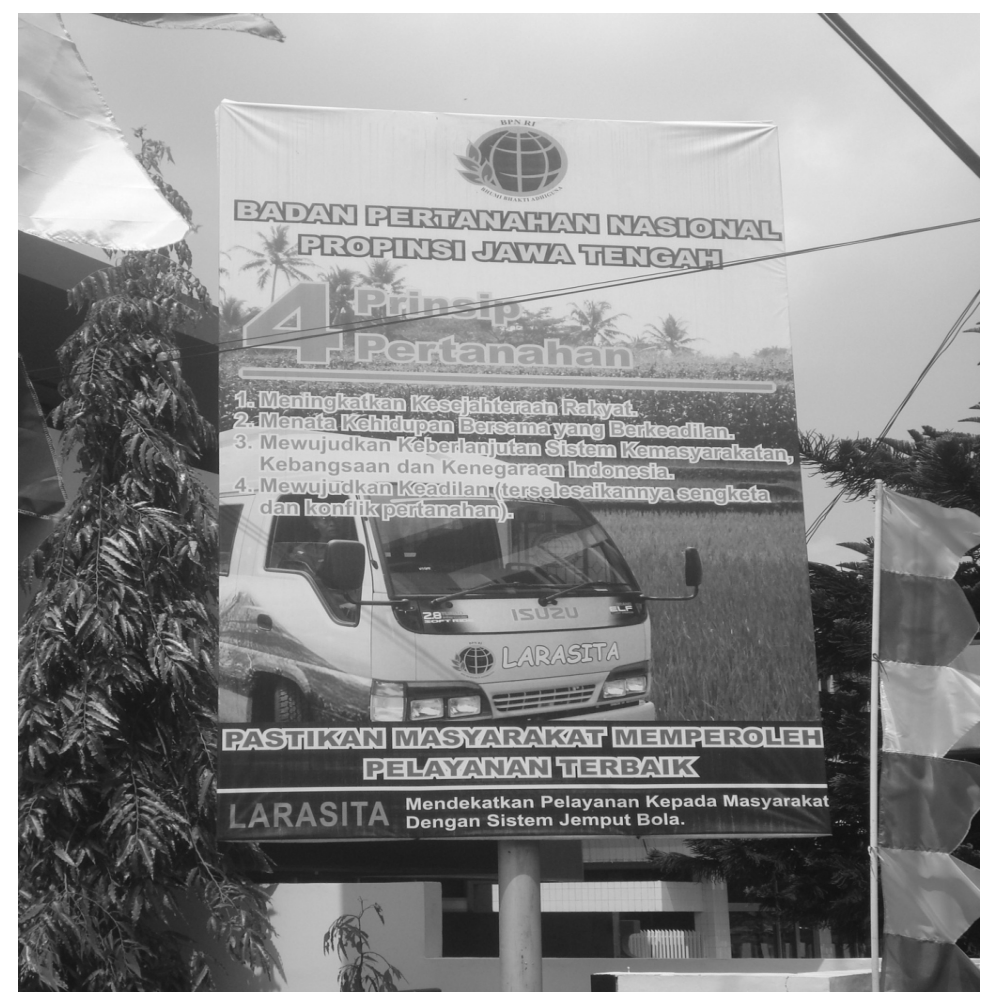

Gambar 2

Iklan Layanan Masyarakat (ILM) "4 Prinsip Pertanahan"

Pada observasi yang penulis lakukan, Jalan Jenderal Soedirman ini dipenuhi oleh iklan luar ruang komersil. Di antara belantara iklan komersil tersebut, hanya beberapa saja iklan layanan masyarakat pemerintah. Ketika penelitian ini dilakukan, penulis menghitung setidaknya ada 7 (tujuh) iklan layanan masyarakat pemerintah yang terpasang di Jalan Jenderal Soedirman. Dari iklan tersebut, ada yang berupa banner, ada baliho, ada juga yang berupa megatron (iklan yang ditempel di video raksasa). Selanjutnya, dari ketujuh iklan tersebut dalam kesempatan ini penulis akan membahas dua iklan yang penulis ambil sebagai kasus.

Iklan layanan pemerintah yang penulis lihat pertama kali adalah iklan Badan Pertanahan Nasional (BPN) di Jalan Jenderal Soedirman No. 356 Banyumas. Sebenarnya pengambilan lokasi iklan tersebut cukup strategis dan sudut yang dipilih, membuatnya mudah dilihat oleh pengendara yang sedang melintas. Namun, sayang sekali banyak pepohonan tumbuh di sekitar iklan tersebut, sehingga menutupi pemandangan dari area jalan, akhirnya iklan tersebut kurang dapat dilihat dengan jelas. Penulis sendiri perlu memutar balik motor karena posisi yang "tidak siap" ketika melihat iklan ini.

Menurut perhitungan penulis, kendaraan yang melewati ruas jalan di mana iklan tersebut berada berkisar pada jumlah 88 kendaraan per menit. Letak iklan yang hanya 100 meter dari lampu merah di perempatan yang sering disebut Perempatan Palma, membuatnya punya potensi diperhatikan, namun mungkin juga justru dilupakan oleh pengendara. Pasalnya, kecenderungan psikologis rata-rata pengendara Indonesia adalah terburu-buru ketika berada di lampu merah. Sehingga, ketika lampu merah tersebut padam, dan berganti dengan lampu hijau, mereka langsung tancap gas dan tentu saja melupakan segala sesuatu yang dilihatnya.

Gambar yang penulis beri judul "4 Prinsip Pertanahan" secara sekilas sudah menunjukkan bahwa tipikal tampilan iklan layanan masyarakat Badan Pertanahan Nasional Provinsi Jawa Tengah tampak sama saja seperti iklan layanan masyarakat lainnya, cenderung formal dan mengobral banyak kata 


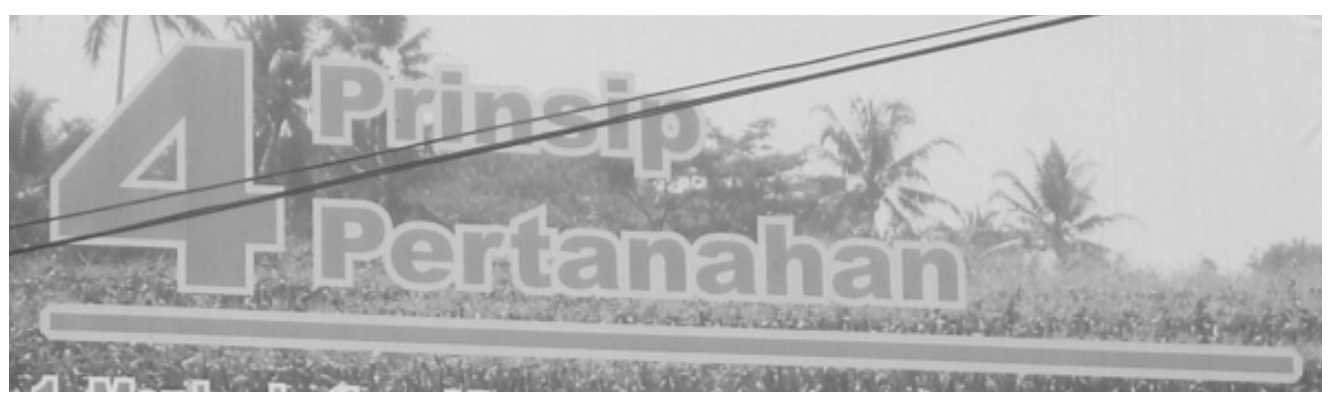

Gambar 3

\section{Headline ILM "4 Prinsip Pertanahan"}

yang tidak perlu. Selain itu, iklan ini tampaknya juga berusaha memanfaatkan ruang (space) secara maksimal. Kelihatan sekali hampir tidak ada ruang kosong yang tersisa, semua dimanfaatkan untuk memberi informasi pada pembacanya. Padahal menurut Lee dan Johnson (2004), meskipun iklan luar ruang memiliki daya lihat yang tinggi, namun waktu lihatnya sangat singkat, yakni sekitar 10 detik saja. Mengingat sedemikian singkatnya waktu yang dimiliki pengendara untuk melihat iklan, iklan luar ruang seperti yang dibuat oleh BPN ini tampak kurang efisien.

Ditinjau dari sisi anatomi, penulis mengacu pada pembagian elemen iklan yang dilakukan oleh Widyatama (2011). Menurut Widyatama, elemen iklan yang lengkap meliputi judul iklan, subjudul iklan, flash (bagian yang berfungsi menonjolkan pesan), tubuh iklan, closer (bagian penutup pesan iklan), ilustrasi, banner (garis paralel yang memisahkan isi iklan dengan keterangan iklan), warna, slogan, dan logo. Meskipun begitu, tidak semua elemen harus masuk ke dalam visualisasi iklan. Tergantung kebutuhannya. Sementara itu, apabila ditinjau visualisasi iklan BPN ini ini tampak cukup lengkap menampilkan beberapa elemennya; seperti judul (headline), tubuh iklan (ad body text), ilustrasi, logo, serta closer yang merangkap sebagai identitas dan slogan.

Dilihat dari tampilan dan penonjolan visual, penulis melihat headline iklan ini adalah kata-kata "4 Prinsip Pertanahan". Ditinjau dari segi tipografi (tampilan huruf) yang dipilih, warna jingga dan pemberian underline (garis bawah) menunjukkan adanya usaha dari designer iklan untuk menonjolkan kata-kata ini melebihi elemen iklan lainnya. Tampaknya, pemilihan warna jingga pada headline ini bertujuan untuk membedakannya dengan background (latar belakang). Kontras warna jingga dianggap mampu "memisahkan dirinya" dengan background yang didominasi oleh warna hijau. Bahkan, sang designer tampak belum puas bermain dengan warna jingga saja, sehingga merasa perlu menambahkan line huruf yang berwarna kuning. Hasilnya, kombinasi warna jingga dan kuning menampilkan kesan dinamis pada headline ini. Font (jenis huruf) yang dipilih berasal dari keluarga san-serif (huruf dengan tanpa kait) agar menambahkan kesan dinamis serta disesuaikan dengan warna huruf. Angka 4 (empat) ditonjolkan dan memenuhi dua baris, sehingga seakan angka ini ingin ditekankan lebih dalam dibandingkan dengan kata-kata setelahnya.

Tubuh iklan (ad body text) dalam iklan ini dituliskan secara lengkap, yang merupakan penjelasan dari headline "4 PRINSIP PERTANAHAN".

Closer Iklan layanan masyarakat "4 prinsip pertanahan" ini adalah slogan yang tampaknya merupakan kata-kata motivasi yang dicanangkan oleh Badan Pertanahan Nasional, "PASTIKAN MASYARAKAT MEMPEROLEH PELAYANAN TERBAIK". Subheadline iklan ini tampak berusaha ditonjolkan oleh designer dengan pemilihan huruf kapital semua. Penonjolan ini juga hendak ditunjukkan dengan pemilihan warna biru terang dengan garis tepi berwarna putih 


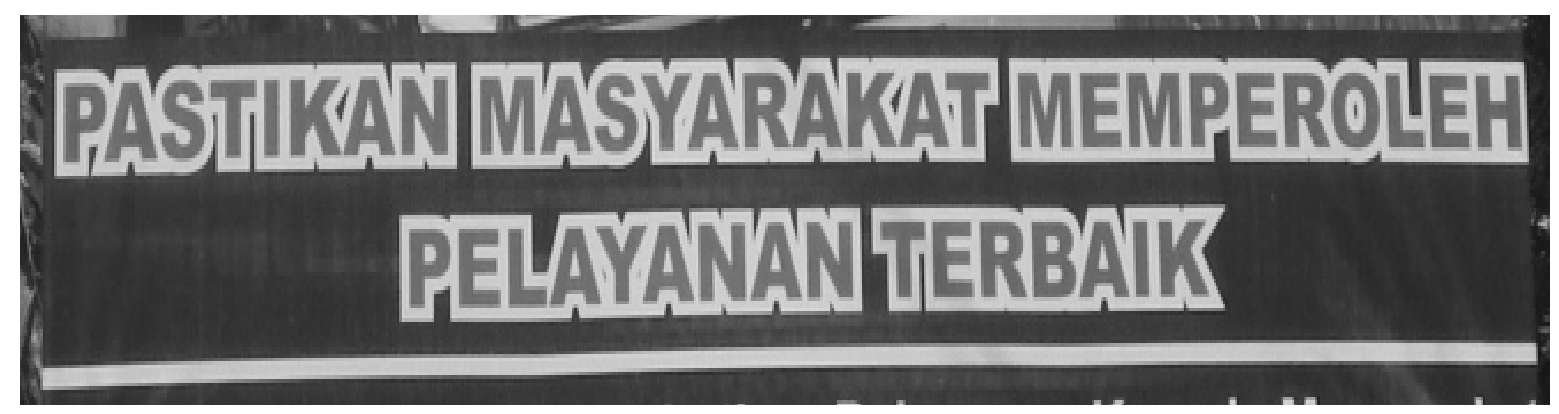

Gambar 4

Subheadline ILM “4 Prinsip Pertanahan”: Terpisah dari Body Iklan?

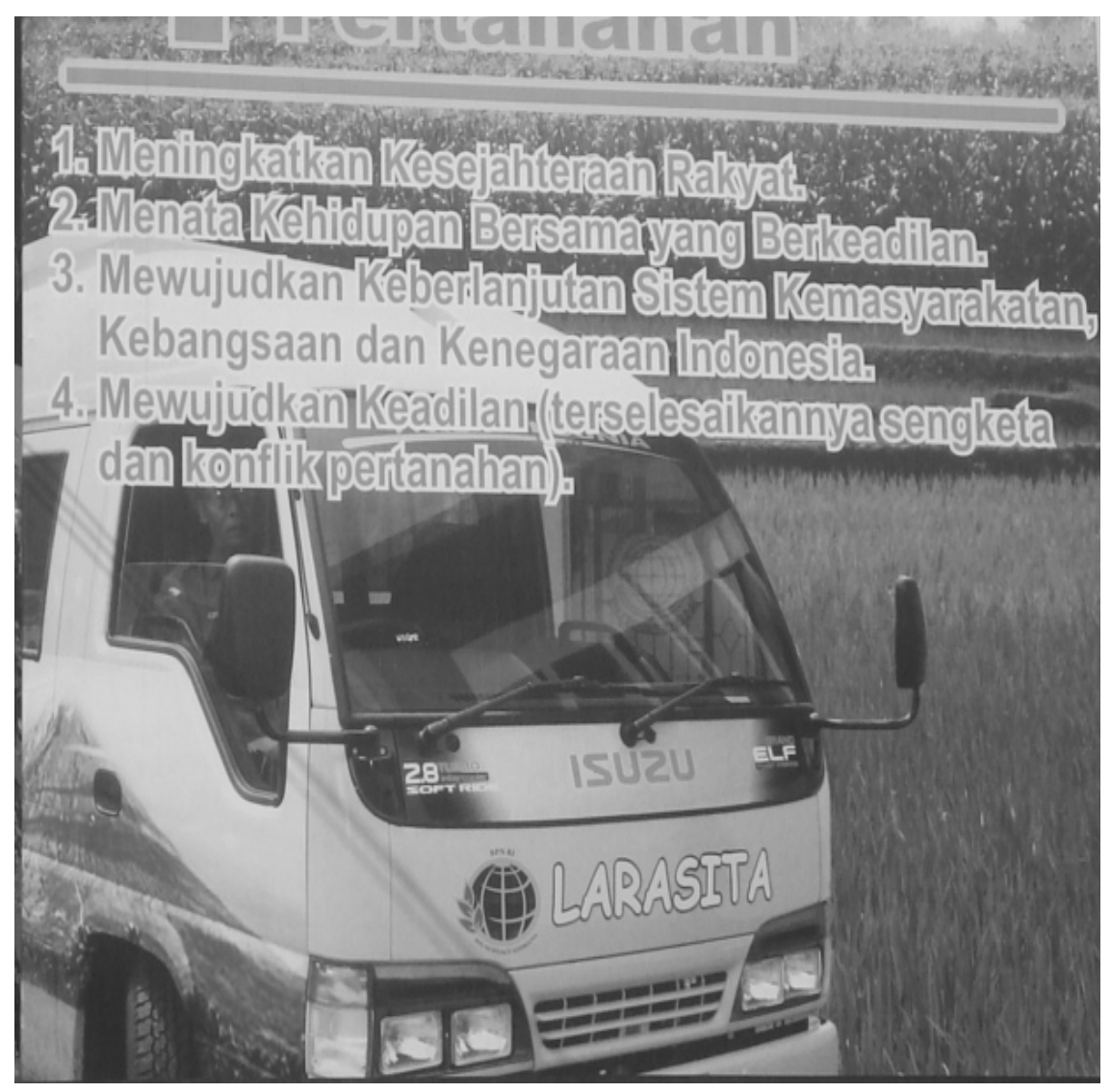

Gambar 5

Ilustrasi ILM “4 Prinsip Pertanahan”: Peneguhan Identitas 
serta kontrasnya dengan latar belakang yang berupa garis hitam, yang sekaligus berfungsi sebagai garis imajiner pemisah antara iklan dengan identitas pembuat. Kesan subheadline ini justru seperti terpisah dengan iklan, karena tidak menyatu dalam kerangka background yang sama. Iklan menggunakan background berupa gambar mobil yang melintas di jalanan perdesaan, sedangkan background subheadline hanyalah warna hitam saja.

Designer iklan layanan masyarakat ini rupanya ingin "memisahkan" lagi antara subheadline tersebut dengan identitas iklan. Terbukti designer menambahkan garis putih di bawah kata-kata "PASTIKAN MASYARAKAT MEMPEROLEH PELAYANAN TERBAIK. Mungkin maksud dari designer adalah memberikan pemisah "sesungguhnya" antara iklan dengan identitas pengiklan. Namun kesannya, jadi ada semacam 2 (dua) pembatas dalam iklan ini. Pertama antara body iklan dengan subheadline, kedua antara subheadline dengan identitas pembuat. Akibatnya, seakanakan ada tiga bidang berbeda dalam satu ruang iklan.

Peran unsur-unsur penyusun iklan tidak dapat dipandang sebelah mata, semuanya mempunyai derajat penting yang sama, seperti pemilihan unsur ilustrasi. Designer iklan ini kelihatannya mencoba mendapatkan fungsi ganda gambar, yakni sebagai ilustrasi sekaligus menjadi background iklan. Gambar yang dipilih adalah sebuah mobil minibus berwarna perak, yang berjalan membelah persawahan di dalam suasana perdesaan. Ilustrasi ini sekaligus merupakan usaha peneguhan identitas pembuat iklan serta citra yang hendak ditampilkan. Logo BPN yang tercetak dengan jelas di bagian depan mobil, serta teks berbunyi LARASITA merupakan identitas yang ditampakkan. Sementara, citra yang hendak ditampilkan adalah kesan kepedulian kepada rakyat kecil dan masyarakat di perdesaan, dan kerelaan bekerja keras dengan cara "menjemput bola", meskipun masyarakat yang dihampiri berada di pelosok perdesaan, bahkan pegunungan. BPN sepertinya ingin menghilangkan citra kantor yang "sulit", di mana untuk melengkapi identitas tanah dibutuhkan waktu yang lama dan proses yang pelik, sehingga menyuburkan praktik percaloan. Melalui gambar ini, masyarakat seperti hendak dijanjikan sebuah bentuk pelayanan prima, semua warga bisa mengakses pelayanan di BPN dan akan dilayani dengan sepenuh hati.

Pada analisis teks verbal, penulis menemukan struktur wacana yang terdiri dari bagian-bagian yang dapat diuraikan pada tabel 1. Bagian (1a) merupakan awal wacana/pembukaan yang berupa identitas; (1b) judul; (1c) tubuh (penjelasan), (1d) penutup berupa slogan; (1e) penutup berupa identitas dan slogan.

Judul pada iklan luar ruang BPN ini memang agak unik, karena tidak diletakkan di bagian awal (atau bagian paling atas iklan). Judul justru diletakkan pada urutan kedua. Meskipun begitu, judul yang diletakkan di urutan kedua masih berada dalam koridor variasi tata letak judul; yakni (1) di awal mendahului subjudul, penjelasan, dan penutup; (2) mengikuti subjudul; (3) mengikuti penjelasan. Namun bagaimanapun, idealnya sebuah judul harus menarik untuk dibaca, dan yang paling penting mampu menjadi jangkar (anchor) dari sebuah iklan cetak sehingga menarik mata pembaca untuk membaca bagian iklan lainnya. Dalam kasus iklan BPN ini, judul hendak dibuat menarik dengan strategi penggunaan ukuran huruf yang lebih besar dibanding yang lain, serta pemilihan warna yang paling mencolok dibanding struktur wacana lainnya.

Penjelasan atau dikenal dengan istilah ad body text merupakan hal yang idealnya harus muncul dalam sebuah wacana. Karena dengan adanya penjelasan, informasi lebih rinci dari sebuah iklan dapat ditangkap oleh pembacanya. Ad body text iklan BPN ini memunculkan penjelasan tentang 4 Prinsip Pertanahan.

Penutup wacana iklan layanan masyarakat 4 Prinsip Pertanahan ini berupa slogan dan identitas pembuat iklan. Pada titik ini, tampaknya pembuat iklan tidak memperhatikan faktor efisiensi dengan menyuguhkan dua identitas (di awal wacana dan di penutup wacana), serta dua slogan (di penutup wacana). 
Tabel 1

\section{Struktur Wacana Iklan BPN “4 PRINSIP PERTANAHAN"}

\begin{tabular}{ll}
\hline (1a) & BADAN PERTANAHAN NASIONAL \\
& Provinsi JAWA TENGAH \\
\hline (1b) & 4 PRINSIP PERTANAHAN \\
\hline (1c) & 1.Meningkatkan Kesejahteraan Rakyat \\
& 2.Menata kehidupan Bersama yang Berkeadilan \\
& 3.Mewujudkan Keberlanjutan Sistem Kemasyarakatan, Kebangsaan, dan Kenegaraan Indonesia \\
& 4.Mewujudkan Keadilan (terselesaikannya sengketa dan konflik pertanahan) \\
\hline (1d) & PASTIKAN MASYARAKAT MEMPEROLEH \\
& PELAYANAN TERBAIK \\
\hline (1e) & LARASITA \\
& Mendekatkan Pelayanan Kepada Masyarakat \\
& Dengan Sistem Jemput Bola \\
\hline
\end{tabular}

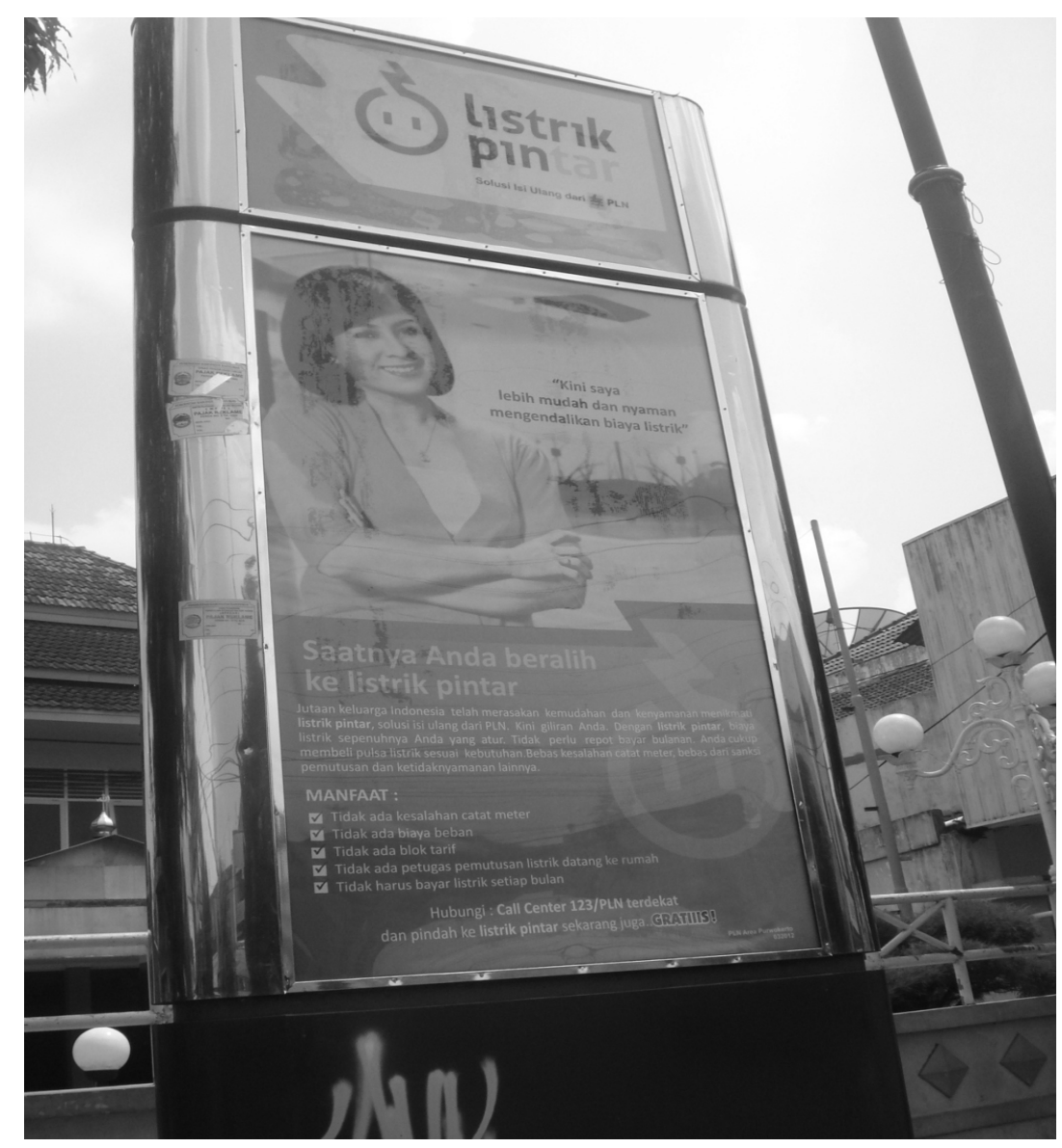

Gambar 6

Iklan "Listrik Pintar" 
Iklan layanan masyarakat lain yang menarik perhatian adalah yang diberi judul "Listrik Pintar". Salah satu iklan layanan masyarakat yang masih berada di kawasan Jalan Jenderal Soedirman Barat terletak di depan kantor Perusahaan Listrik Negara (PLN) Banyumas. Iklan yang cukup menarik ini menampilkan visualisasi ilustrasi seorang perempuan muda berambut pendek yang memakai baju berwarna kuning sedang bersedekap sambil tersenyum menghadap ke arah pembaca. Tampak background gambarnya adalah sebuah gedung yang mirip kantor. Iklan ini didominasi warna biru dengan berbagai variannya, serta warna kuning pada baju model.

Iklan Listrik Pintar ini dibagi menjadi dua bagian, yang dipisahkan beberapa sentimeter rongga jarak. Bagian pertama yang ada di atas adalah judul, logo, dan subjudul yang sekaligus menjadi slogan iklan. Sedangkan bagian kedua terletak di bawah yang berisi ilustrasi, ad body text, identitas, serta closer. Secara umum visualisasi iklan ini sudah cukup lengkap, namun ada hal yang mengurangi nilai desain yakni sudut iklan terhadap jalan. Posisi iklan yang sejajar dengan jalan kurang ideal dibaca, iklan akan lebih nyaman dibaca apabila membentuk sudut terhadap jalan. Namun, kekurangan tata letak ini tertutup dengan desain iklan luar ruang yang eksklusif.

Headline di bagian awal iklan tampak smart, sesuai dengan judulnya: "Listrik Pintar". Designer dengan cerdas memilih font yang tidak biasa pada kata-kata "Listrik Pintar" tersebut, sehingga headline tampak menonjol meskipun tidak menggunakan huruf kapital. Pemilihan warna pada kalimat headline juga tepat, di mana dominasi warna biru tampak jelas di sini. Meskipun background-nya berwarna biru juga, namun ini tidak mengurangi kontras antara foreground dengan background, karena derajat warna birunya yang berbeda. Designer juga dengan jeli memanfaatkan kombinasi warna pada kalimat headline, di mana ada dua warna dalam satu kalimat listrik pintar, menjadi "listrik pin-tar". Entah karena kebetulan atau memang sengaja, solusi listrik PLN yang dinamakan listrik pintar ini memang menggunakan PIN atau dikenal dengan istilah token. Jadi, pelanggan membeli pulsa dengan nominal tertentu, kemudian mereka akan menerima token yang berisi 20 angka untuk dijadikan PIN sebagai tanda membeli pulsa listrik. PIN tersebut kemudian diketik di meteran listrik. Bila itu benar, maka sekali lagi designer iklan ini telah sukses menggabungkan estetika dan filosofi desain. Copywriter iklan ini juga patut diacungi jempol. Pemilihan diksi listrik pintar sudah berhasil memberikan judul yang menarik bagi pembaca iklan. Orang akan cenderung lebih tertarik untuk mengetahui apa yang dimaksud dengan listrik pintar ini.

Berbeda dengan iklan BPN yang dibuat dan didesain lokal, iklan listrik pintar ini didesain secara nasional. Artinya iklan ini visualisasinya hampir sama di seluruh Indonesia. Sehingga, wajar saja kiranya apabila desainnya berkesan lebih rapi.

Pada headline listrik pintar ini terdapat penciri yang berfungsi sebagai anchor atau jangkar perhatian, yakni logo. Logo yang tampak mencolok ini merupakan bentuk stilasi sebuah stop kontak dengan lambang petir di atasnya. Stop kontak itu akhirnya menjadi mirip wajah orang dengan rambut yang unik. Logo ini sekaligus dapat menjadi sebuah representasi ikonik orang yang cerdas. Melihat logo tersebut, pembaca iklan sudah pasti paham bahwa itu adalah sebuah bentuk stop kontak. Pembaca iklan yang teliti tentunya akan memahami kemudian bahwa itu merupakan representasi dari penggunaan stop kontak secara pintar. Intinya adalah agar pelanggan listrik selalu memperhatikan penggunaan listriknya.

Berpindah ke tubuh iklan, tampak ilustrasi seorang perempuan serta banyak teks yang menjelaskan mengenai listrik pintar. Mirip dengan iklan BPN, iklan listrik pintar ini kelihatan ingin banyak memberikan informasi padahal ruangan untuk iklan hanya sedikit. Sebenarnya ini tidak efektif, mengingat iklan luar ruang seharusnya dapat dibaca dalam sekilas saja. Namun setidaknya, pemilihan font sanserif serta beberapa permainan warna membuat poin-poin penting dalam tubuh iklan ini tidak terlewatkan oleh pengguna jalan. Misalnya saja dengan adanya 


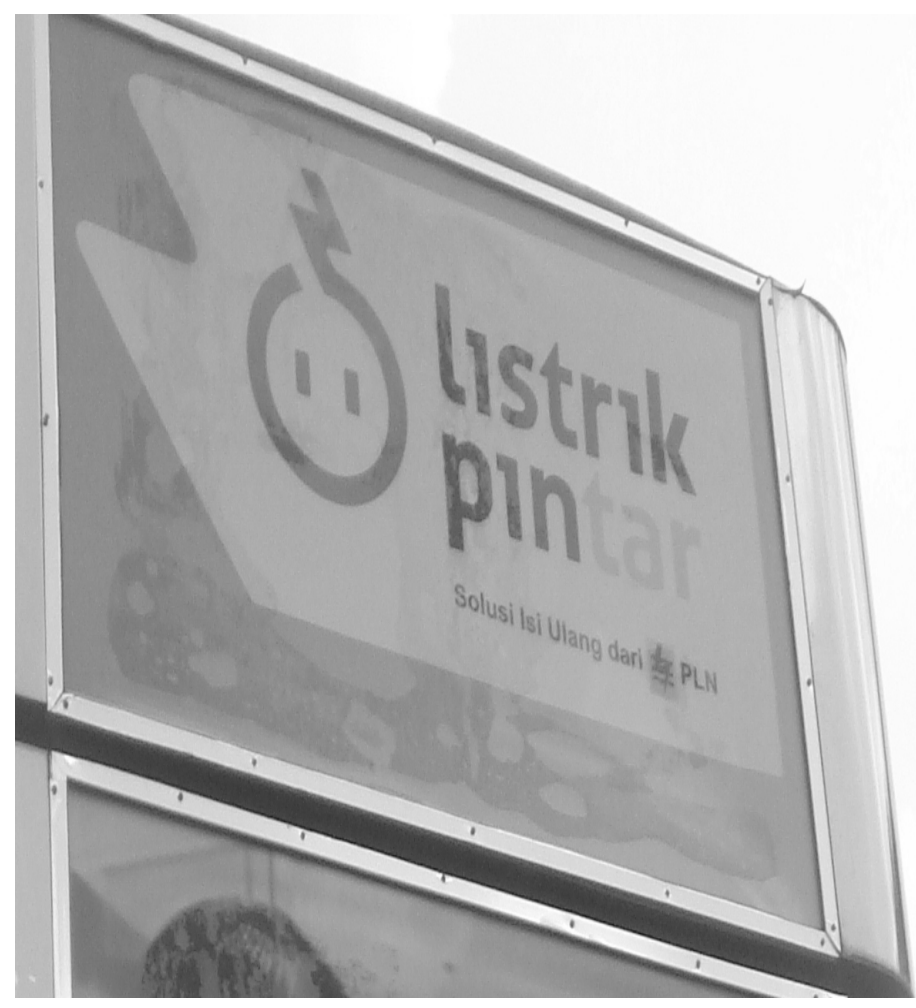

Gambar 7

Headline Smart Iklan Listrik Pintar

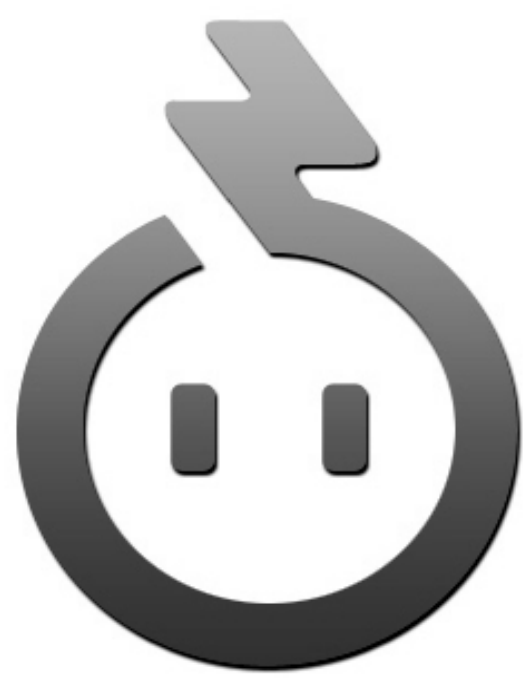

Gambar 8

Logo Listrik Pintar 


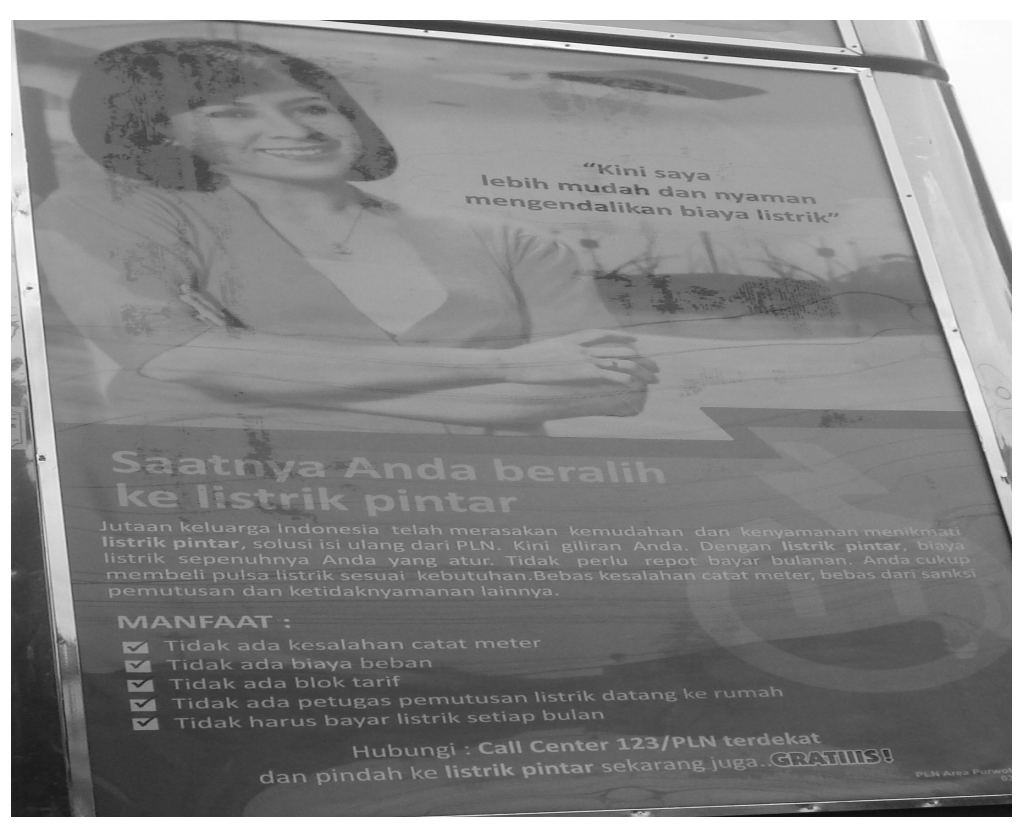

Gambar 9

Tubuh Iklan Listrik Pintar

teks anchor: "Saatnya anda beralih ke listrik pintar", yang berukuran lebih besar daripada teks lainnya. Warna teks anchor yang senada dengan ilustrasi membuatnya semakin terlihat jelas dan berbeda.

Anchor lain yang tampak pada badan iklan adalah ilustrasi gambar perempuan yang tampak sedang tersenyum sambil melihat pada pembaca iklan. Hal pertama yang menarik perhatian adalah pakaian yang dikenakannya. Pakaian tersebut berupa baju formal dengan warna yang cerah. Latar belakang gambar ilustrasi yang berupa gedung perkantoran menguatkan penekanan pada pakaian formal perempuan tersebut. Designer iklan tampak ingin menyampaikan pesan bahwa perempuan tersebut merupakan sosok karir yang bekerja di sebuah kantor resmi. Sejalan dengan ini, Danesi (2010) menyatakan bahwa gaya pakaian formal merupakan evolusi dari cara berpakaian kaum Puritan yang mendasarkan kehidupannya pada sikap hemat, rajin, menahan diri, dan giat bekerja. Poin pokok pada penelusuran ini adalah makna bahwa gaya pakaian formal yang diilustrasikan pada gambar merupakan simbolisasi pada kelompok manusia yang bersikap hemat, dan menahan diri untuk tidak menghambur-hamburkan uangnya.
Sementara itu, penggunaan tokoh anonim dalam ilustrasi dapat berarti semua orang, atau orang biasa. Artinya semua orang atau orang biasa dapat memanfaatkan listrik hemat. Sedangkan pemilihan sosok perempuan juga bukan tanpa alasan. Dalam sebuah rumah tangga, seringkali perempuan lah yang memegang kendali keuangan. Perempuan juga yang menentukan mahalmurahnya sebuah harga. Apabila sesosok perempuan mengatakan sebuah produk murah, kemungkinan besar produk tersebut benar-benar murah. Di sisi lain perempuan merupakan penarik perhatian. Merupakan objek yang membuat sesuatu menjadi menarik. Menurut Williamson (2007) Perempuan (dalam media) 'sepenuhnya dibentuk oleh tatapan lelaki'. Williamson menambahkan bahwa meskipun di iklan ini tidak lelaki, namun mereka sekaligus ada di mana-mana. Perempuan ini ditakdirkan untuk memandang dirinya sendiri melalui mata sang lelaki. Dalam konteks iklan ini, perempuan tersebut tidak semata-mata memandang semua lelaki, namun lebih memandang kepada kepala keluarga (suami) agar memilih listrik pintar.

Satu kelemahan badan iklan ini adalah teks yang terlalu banyak untuk ukuran ruang 


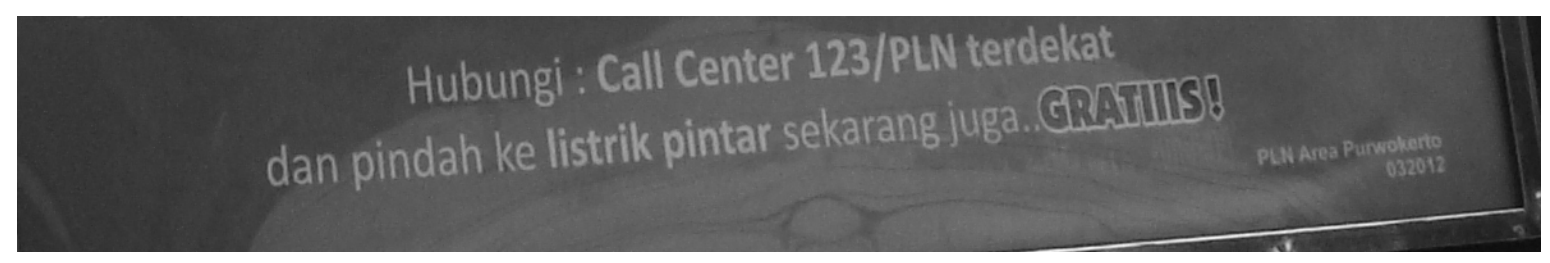

\author{
Gambar 10 \\ Closer Iklan Listik Pintar
}

Tabel 2

Struktur Wacana Iklan "Listrik Pintar"

\begin{tabular}{ll}
\hline (2a) & listrik pintar \\
& Solusi Isi Ulang dari PLN \\
\hline (2b) & "Kini saya lebih mudah dan nyaman mengendalikan biaya listrik" \\
& Saatnya Anda beralih ke listrik pintar \\
& Jutaan keluarga Indonesia telah merasakan kemudahan dan kenyamanan menikmati listrik pintar, solusi \\
& isi ulang dari PLN. Kini Giliran Anda. Dengan listrik pintar, biaya listrik sepenuhnya Anda yang atur. \\
& Tidak perlu repot bayar bulanan. Anda cukup beli pulsa listrik sesuai kebutuhan. Bebas kesalahan catat \\
& meter, bebas dari sanksi pemutusan, dan ketidaknyamanan lainnya. \\
& MANFAAT: \\
& -Tidak ada kesalahan catat meter \\
& -Tidak ada biaya beban \\
& -Tidak ada blok tarif \\
& -Tidak ada petugas pemutusan listrik datang ke rumah \\
& -Tidak harus bayar listrik setiap bulan \\
Hubungi : Call Center 123/PLN terdekat \\
Dan pindah ke listrik pintar sekarang juga. GRATIIIS! \\
PLN Area Purwokerto \\
032012
\end{tabular}

yang sempit. Penulis menghitung, terdapat 99 kata dalam badan iklan tersebut. Sehingga, orang membutuhkan waktu khusus hanya untuk mengetahui isinya. Persoalannya adalah: apakah pengguna jalan cukup punya waktu untuk membacanya? penulis memperkirakan jawabannya tidak.

Iklan ini ditutup oleh closer yang cukup rapi. Kata yang paling menarik dari penutup ini mungkin adalah kata "GRATIIIS!" yang ditulis dengan huruf kapital, ukuran font yang lebih besar daripada lainnya, serta warna yang berbeda. Kelemahan closer iklan ini adalah letaknya yang tidak terpisah dengan ad body, sehingga memungkinkan orang kebingungan. Biasanya dalam sebuah desain iklan, letak closer ini selalu dipisahkan dari ad body baik dengan garis ataupun dengan warna latar belakang.

Dalam analisis teks verbal iklan layanan masyarakat "listrik pintar", penulis menjumpai beberapa hal yang dapat diuraikan dalam tabel 2. Tabel 2 menunjukkan model struktur iklan sebagaimana yang dikemukakan oleh Bolen (dalam Rani et.al, 2006); yakni terbagi menjadi (1) butir utama (headline); (2) badan (body); (3) penutup (closer).

Apabila dibahas secara mendetail, baris (2a) merupakan butir utama iklan yang tujuannya adalah menarik perhatian. Apabila dikaitkan dengan kategorisasi dari Bolen, maka butir utama iklan ini menggunakan "proposisi yang membangkitkan rasa ingin tahu konsumen". Kata-kata "listrik pintar, solusi isi ulang dari PLN" mendorong pembaca untuk mengetahui lebih lanjut dengan panduan pertanyaan: (1) apakah listrik pintar itu?; (2) bagaimanakah solusi yang hendak ditawarkan PLN?. 
Pertanyaan-pertanyaan mengenai iklan ini dijawab pada badan iklan, yang dalam konteks iklan ini diwakili oleh baris (2b). Menurut Bolen, dengan berdasar pada motif calon konsumen dalam membeli sesuatu, yaitu motif emosional dan motif rasional, maka bagian badan wacana iklan hendaknya mengandung alasan subjektif (emosional) dan alasan objektif (rasional). Konteks iklan listrik pintar, alasan yang dipakai adalah objektif (rasional), yakni dengan menampilkan keuntungan-keuntungan yang bisa didapatkan pelanggan PLN apabila menggunakan skema listrik pintar. Teks yang panjang lebar pada ad body telah cukup menjelaskan tentang keuntungan-keuntungan rasional tersebut. Secara wacana teks iklan ini lengkap dan informatif, namun dari sisi desain kurang efektif.

Penutup iklan, dalam konteks iklan listrik pintar ini, berisi informasi-informasi lain yang berhubungan dengan topik utama. Kata-kata: "Hubungi Call Center 123/PLN terdekat" merupakan informasi tentang nomor telepon dan tempat pelayanan yang dapat dikontak pembaca. Sementara kata-kata "pindah ke listrik pintar sekarang juga... GRATIIIS!" adalah informasi yang mendorong tindakan dari pembaca iklan. Kalimat seperti ini biasanya berupa kalimat perintah.

\section{PENUTUP}

\section{Simpulan}

Kuantitas atau jumlah iklan layanan masyarakat relatif kecil. Di Jalan Jenderal Soedirman yang merupakan salah satu jalan protokol di Banyumas, hanya terdapat beberapa buah iklan masyarakat saja. Apabila jumlah iklan layanan masyarakat dibandingkan dengan jumlah iklan komersial, maka akan terlihat sekali ketimpangannya.

Hal ini menjadi sebuah pekerjaan rumah bagi pemerintah. Karena, iklan layanan masyarakat sama pentingnya dengan iklan komersil. Sehingga, selayaknya iklan layanan masyarakat kuantitasnya ditambah. Selain itu, kualitas iklan layanan masyarakat juga perlu diperbaiki. Meskipun iklan layanan masyarakat sifatnya hanya penguat dari sosialisasi pemerintah yang bersifat struktural, namun tidak ada salahnya pemerintah mengusahakan iklan yang dibuat dapat menjadi seprofesional mungkin.

Dari hasil penelitian, iklan layanan masyarakat juga belum dapat dikatakan maksimal kualitasnya. Hal ini bisa saja muncul karena ketidaktahuan designer tentang prinsip-prinsip dasar desain, atau memang karena pesanan dari sang penyandang dana yang tidak paham desain. Gejala tidak maksimalnya kualitas desain adalah dari sisi kreativitas desain, layout halaman iklan, hingga pemilihan font.

Hal yang paling mencolok dari kekurangan desain iklan layanan masyarakat adalah kesan sesaknya ruang iklan oleh pesan. Seakan-akan designer ingin memasukkan semua pesan dalam satu ruang kecil iklan. Padahal hal ini tidak diperkenankan dalam prinsip desain iklan. Apalagi media yang digunakan adalah luar ruang yang seharusnya dapat dilihat dalam tempo beberapa detik saja.

Namun begitu, dari sisi verbalisasi iklan, tampak iklan luar ruang layanan masyarakat pemerintah ini telah memenuhi unsur wacana lengkap. Meskipun kadangkadang tampak proposisi yang masih kaku dan dipenuhi oleh gaya penulisan yang formal.

Dengan demikian, secara umum pemerintah telah mengemas pesan dalam iklan layanan masyarakat secara cukup baik dengan menggunakan tata bahasa yang sesuai kaidah bahasa Indonesia yang baik dan benar. Namun pesan yang baik itu tidak diiringi dengan tata letak desain komunikasi visual yang memadai sehingga berpotensi tidak diperhatikan masyarakat.

\section{Saran}

Instansi pemerintah di bidang periklanan, sebaiknya membenahi dan memperbaiki tata letak dan kalimat-kalimat pada iklan layanan masyarakat yang ditampilkan pada media luar ruang, agar lebih menarik masyarakat untuk memperhatikan dan membacanya. Hal ini akan berdampak pada partisipasi aktif 
masyarakat dalam pembangunan.

Pemerintah hendaknya memperhatikan cara penyampaian pesan melalui iklan luar ruang. Karena iklan inilah yang setiap hari bersentuhan langsung dengan masyarakat, berbiaya murah, dan bertahan lama.

\section{DAFTAR PUSTAKA}

\section{Buku:}

Danesi, Marcell. (2010). Pesan, Tanda, dan Makna: Buku Teks Dasar Mengenai Semiotika dan Teori Komunikasi. Penerjemah: Evi Setyarini dan Lusi Lian Piantari. Yogyakarta: Jalasutra.

Dyer, Gillian. (1982). Advertising as Communication. London: Routledge

Fachruddin. (1988). Dasar-dasar Keterampilan Menulis. PLLPTK.

Hadi, Umar. (2007). Seni dalam Desain Komunikasi Visual. Dalam : Widyatmoko, FX.ed. Irama Visual: dari Toekang Reklame sampai Komunikator Visual. Yogyakarta: Jalasutra pp. 03-12

Halliday, M.A.K. \& Hasan, Ruqaiya. (1992). Bahasa Konteks, dan Teks: Aspek-aspek Bahasa dalam Pandangan Semiotik Sosial. Penerjemah: Asruddin Barori Tou. Yogyakarta: Gadjah Mada University Press.

Jefkins, Frank. (1997). Periklanan. Penerjemah: Haris Munandar. Editor: Yati Sumiharti. Jakarta: Erlangga

Kasali, Rhenald. (1995). Manajemen Periklanan. Jakarta: Grafiti.

Lee, Monle and Johnson, Carla. (2004). Prinsip-prinsip Pokok Periklanan dalam Perspektif Global. Jakarta: Prenada Media.

Liliweri, Alo. (1992). Dasar-dasar Komunikasi Periklanan. Bandung: Citra
Aditya Bakti.

Manser, Martin. (1995). Oxford Dictionary New Edition. Oxford: Oxford University Press.

Miles, Mathew B. dan A. Michael Huberman. (1992). Analisis Data Kualitatif: Buku Sumber tentang Metode-metode Baru. Cetakan Pertama. Jakarta: UniversitasIndonesia Press.

Moleong, Lexy. (2007). Metodologi Penelitian Kualitatif. Bandung: PT Remaja Rosdakarya.

Nuradi. (1996). Kamus Istilah Periklanan Indonesia. Jakarta: PT Gramedia Pustaka Utama.

Pujiriyanto. (2005). Teori Grafis Komputer. Yogyakarta: Penerbit Andi.

Rose, Gillian. (2001). Visual Methodologies. California: Sage Publications Ltd.

Supriyono, Rakhmat. (2010). Desain Komunikasi Visual: Teori dan Aplikasi. Yogyakarta: Penerbit Andi.

Susanto, Astrid S. (1989). Komunikasi dalam Teori dan Praktek. Bandung: Binacipta

Sumartono. (2002). Terperangkap dalam Iklan. Jakarta: Penerbit Alfabeta.

Widyatama, Rendra. (2011). Teknik Menulis Naskah Iklan agar Tepat Kena Sasaran. Yogyakarta: Cakrawala.

Williamson, Judith. (2007). Decoding Advertisements: Membedah Ideologi dan Makna dalam Periklanan. Penerjemah: Saleh Rahmana. Editor: Alfatri Adlin. Yogyakarta: Jalasutra.

\section{Sumber lainnya: \\ Jurnal:}

Cenadi, Christine S. (1999). Elemen-elemen dalam Desain Komunikasi Visual. Jurnal NIRMANA, Vol. 1 No. 1 Januari hal. 01-11. 